\title{
Zapojení doktorských studentů do výzkumných projektů (zkušenosti se specifickým výzkumem) ${ }^{1}$
}

\author{
Josef Šaur (Brno)
}

\begin{abstract}
Abstrakt
Příspěvek vyhodnocuje dosavadní zkušenosti Ústavu slavistiky FF MU s granty specifického vysokoškolského výzkumu, tj. s projekty zaměřenými na podporu publikační činnosti doktorandů. Tyto projekty řeší Ústav slavistiky pravidelně od roku 2010. Jedná se o projekty krátkodobé, trvající vždy jeden kalendářní rok. Kromě prípravy vystoupení na tuzemských i zahraničních konferencích je od roku 2013 vždy výstupem takového projektu kolektivní publikace doktorandů a pracovníků ústavu.
\end{abstract}

\section{Klíčová slova}

slavistika; výzkum; projekty; doktorští studenti; Ústav slavistiky

\section{Abstract \\ Involvement of PhD Students in Research Projects (Experience with Specific University Research Grants)}

The paper evaluates the experience of the Department of Slavonic Studies at the Faculty of Arts, Masaryk University, with the Specific University Research Grants, i.e. projects focusing on the support of publishing activities of $\mathrm{PhD}$ students. These projects have been solved at the Department of Slavonic since 2010. The projects are short-term lasting always for one calendar year. Apart from preparations to present at local as well as foreign conferences, the output of the projects has always been joint publication of doctoral students and the department staff since 2013.

\section{Key words}

Slavonic studies; research; projects; PhD students; Department of Slavonic Studies

1 Tato studie vznikla na Ústavu slavistiky Filozofické fakulty Masarykovy univerzity v rámci projektu Stimulace a podpora interdisciplinárního slavistického výzkumu číslo MUNI/A/1125/2014 podpořeného z prostředků účelové podpory na specifický vysokoškolský výzkum, kterou poskytlo MŠMT v roce 2015. 
Nedílnou součástí univerzitního vzdělávání je také výchova mladých badatelů, kteří navazují na práci svých univerzitních učitelů. Nikoliv výjimečně se hovoří o vědeckých školách, někdy dokonce takové školy nesou jméno významné univerzitní osobnosti, jež stála u jejích počátků. Ostatně jednou z podmínek profesorského jmenovacího řízení je vedení doktorských studentů a minimálně jeden absolvent doktorského studia. Přípravu nadějných studentů na akademickou dráhu je dnes možné podpořit z prostředků specifického vysokoškolského výzkumu. V následujících odstavcích si dovolím představit zkušenosti Ústavu slavistiky Filozofické fakulty s tímto druhem finanční podpory.

Nejprve si stručně přibližme, co se rozumí tzv. specifickým výzkumem. ${ }^{2}$ Jedná se o účelové finanční prostředky určené $\mathrm{k}$ podpoře grantů menšího rozsahu. Specifický výzkum jako celek spravuje Ministerstvo školství, tělovýchovy a mládeže ČR. Granty jsou administrovány jednotlivými univerzitami, které mají na starosti jak grantovou soutěž, tak i čerpání přidělených prostředků. Granty jsou krátkodobé s dobou řešení jeden rok (vždy řešeno od 1. 1. do 31. 12.).

Specifičnost avizovaná v názvu účelové podpory spočívá v zaměření na studenty doktorského, prrípadně magisterského studia. „Cílem podpory je posíleni samostatné tvưrči činnosti studentů v oblasti výzkumu a vývoje směrujici $k$ intenzivnimu zapojeni studentů do problematiky řš̌ené zejména v rámci týmové výzkumné a vývojové činnosti na fakultách. " ${ }^{3}$ Nicméně do řešení projektů podpořených ze specifického výzkumu jsou zapojeni jak studenti, tak i akademičtí pracovníci. Jedná se tedy o skutečně specifickou záležitost, která má některé rysy společné s juniorskými i seniorskými grantovými rámci. Primárně však cílí na výchovu vědeckého dorostu a umožňuje podpořit i takový výzkum, který by v jiných grantových soutěžích neměl naději na úspěch.

Podpora je poskytována ve dvou kategoriích. V první z nich (kategorie A) jsou předkládány „standardní“ výzkumné projekty v jednotlivých vědách. Ve druhé (kategorie B) jsou podporovány projekty zaměřené na pořádání a organizaci studentských vědeckých konferencí. S ohledem na vytyčené cíle specifického výzkumu platí, že osobní náklady na studenty musí činit více jak $60 \%$ celkových osobních nákladů a počet studentů zapojených do projektu musí být více jak $50 \%$ z celkového počtu zapojených osob.

Dosud podpořené projekty, řešené pracovníky a studenty Ústavu slavistiky FF MU, měly vždy svoji osobitou náplň danou zkoumaným tématem, nicméně vykazují jisté shodné obecné rysy. V souladu s podstatou specifického výzkumu bylo a je hlavním cílem těchto projektů podpora publikační činnosti doktorandů. Výstupy výzkumu jsou proto především vystoupení na konferencích (at’ již studentských či standardních) a v případě zkušenějších doktorandů i články v odborných periodicích (českých i těch vydávaných v různých slovanských zemích). Od roku 2013 se pak stalo pravidlem, že projekt specifického výzkumu završuje kolektivní publikace doktorandů slavistiky, do nichž přispíva-

2 Ke specifickému výzkumu srov. informace na internetových stránkách Masarykovy univerzity a MŠMT, kde je dostupná i část projektové dokumentace (část dokumentace je ovšem neveřejná, nebở se jedná o institucionální know-how). [online]. [Cit. 28. 1. 2016]. Dostupné z: http://vyzkum.rect.muni.cz/cs/ projektova-podpora/interni-projekty/specificky-vyzkum a [online]. [Cit. 28. 1. 2016]. Dostupné z: http:// www.msmt.cz/vyzkum-a-vyvoj/specificky-vysokoskolsky-vyzkum.

3 Ibidem. 
jí i akademičtí pracovníci ústavu, avšak studenti vždy tvoří v autorském kolektivu jednoznačnou většinu.

V jistém ohledu jsou součástí výstupů i recenze na nejnovější odbornou literaturu, zpracovávanou v průběhu výzkumu. Ovšem tyto výstupy nejsou vykazovány, protože se nepřenáší do RIV.

Samotné řešení projektových záměrů je pojato jako „dílna“, tj. věda je chápána jako „řemeslo“, kterému se mladší generace učí pod vedením zkušenějších badatelů. Důraz je kladen zejména na to, aby se studenti seznámili s průběhem př́ípravy publikačního výstupu - počínaje přípravou rukopisu, jeho recenzním posouzením, zapracováním připomínek recenzentů, přes komunikaci se sazečem, prací na korekturách a konče předáním publikace do tisku.

Výhodou specifického výzkumu je, že grantová soutěž umožňuje i projekty se širokou obsahovou náplní. To konvenuje pracovnímu zaměření Ústavu slavistiky, který jakožto filologické pracoviště sdružuje literární vědce a lingvisty, přičemž nejsou opomíjena ani kulturní a areálová studia. ${ }^{4}$ Všechny dosud řešené projekty se slavistickou tematikou proto obsahovaly komponentu literárně vědnou, lingvistickou i areálovou a navíc se vždy zaměřovaly na celý slovanský areál (případně jeho vybranou signifikantní část).

Navrhovatelé projektů přitom vycházeli z předpokladu, že právě prostor střední, východní a jihovýchodní Evropy (slovanský i neslovanský) sdílel a sdílí řadu společných dějinných zkušeností, které se promítají do literatur, kultur a jazyků tohoto areálu. Jedná se o země střední Evropy, Balkánu a bývalého Sovětského svazu, které vykazují četné společné jmenovatele. Pro pochopení těchto změn jsou důležité jak jejich synchronní příčiny, tak i jejich diachronní ukotvení. Jak projektové návrhy, tak i schválené projekty vždy přihlížely ke skutečnosti, že není možné postihnout v ročním projektu všechny současné trendy ve slovanských literaturách, kulturách a jazycích a dostatečně osvětlit jejich příčiny. Z tohoto důvodu bylo řešení výzkumných úkolů prováděno formou sond.

Z hlediska skladby nákladů, kopírují projekty specifického výzkumu běžné humanitně zaměřené grantové projekty. Jelikož jejich řešení nevyžaduje speciální př́ístrojové vybavení či nákladný spotřební materiál, tvoří převážnou část osobní náklady, a to především stipendia, jimiž je honorována badatelská činnost studentů.

Prvním projektem financovaným ze specifického výzkumu na Ústavu slavistiky FF MU byl projekt Role tzv. malých kultur ve středoevropském a jihoslovanském areálu řešený v roce 2010. Jednalo se o skromné počátky, nebot do výzkumu byli zapojeni dva doktorští studenti a dva akademičtí pracovníci. Díky finanční podpoře se realizovaly dvě vystoupení na konferencích a mohly vzniknout tři studie.

$\mathrm{S}$ nabytými zkušenostmi se $\mathrm{v}$ dalších letech postupně rozrůstal řešitelský tým, a to především z hlediska počtu zapojených studentů..$^{5} \mathrm{~V}$ roce 2014 (projekt Současné

4 K tomu srov. POSPÍŠIL, Ivo: Areál a filologická studia. Brno: Masarykova univerzita, 2013; POSPÍŠIL, Ivo (ed.): Areál - sociálni vědy - filologie. Brno: Masarykova univerzita, 2002; POSPÍŠIL, Ivo - GAZDA, Jiří - HOLZER, Jan: Integrovaná žánrová typologie: (komparativni genologie): projekt, metodologie, terminologie, struktura oboru, studie. Brno: Masarykova univerzita, 1999.

$5 \quad \mathrm{Z}$ prostorových důvodů se věnujeme v textu podrobněji projektům řešeným v letech 2014 a 2015 . Jen pro úplnost uvádíme názvy projektů za předcházející léta: Slovanské areály (2011), Slované a slavistika v areá- 
trendy ve výzkumu slovanských literatur, jazyků a kultur) již bylo zapojeno 17, v roce 2015 (projekt Stimulace a podpora interdisciplinárního slavistického výzkumu) 18 studentů. Rostl také počet dosažených výstupů. V roce 2014 se jednalo o jednu knihu, 12 vystoupení na konferencích, dva články v odborných časopisech, ${ }^{6}$ osm článků ve sbornících ${ }^{7}$ a jednu disertaci. V roce 2015 pak vznikla společná publikace sedmi doktorandů a tří akademických pracovníků a dále pět článků v odborných časopisech, ${ }^{8}$ dvě kapitoly v odborné knize, ${ }^{9}$ sedm článků ve sbornících ${ }^{10}$ a sedm vystoupení (prezentací) na konferencích.

lovém pojeti (2012) a Kontrasty města v současných slovanských (a vybraných balkánských neslovanských) literaturách, kulturách a jazycích (2013).

6 STEHLÍK, Petr: Bosna, Zach i Načertanije: O nekim aspektima programa Ilije Garašanina iz 1844. godine. Slavistika18, 2014, s. 353-360; POSPÍŠIL, Ivo: Cyrilometodějské výroči a problémy jeho současné recepce (Několik tezi a paradoxů misto úvodního slova). Slavica litteraria 17, 2014, č. 1, s. 5-24.

7 KREJČÍ, Pavel: Hudebni motivy s numerickými komponenty v české, chorvatské, srbské a bulharské frazeologii. In: Frazeologické štúdie VI. Hudobné motívy vo frazeológii, 26.-27. september 2014. Ed. Mária Dobríková. Bratislava: Univerzita Komenského v Bratislave, 2014, s. 168-179; KREJČOVÁ, Elena: Frazeologizmi $s$ komponent Tăpan/baraban v bălgarski ezik. In: Frazeologické štúdie VI. Hudobné motívy vofrazeológii, 26. - 27. 9. 2014. Ed. Mária Dobríková. Bratislava: Univerzita Komenského v Bratislave, 2014, s. 180-190; KREJČOVÁ, Elena: Predizvikatelstvata pred novite uchebni pomagala po t.nar. „malki slavjanski ezici“. In: IVANOVA, Diana (ed.): Ezikova politika v evropejski i nacionalen kontekst. Plovdiv: Universitetsko izdatelstvo „Paisij Chilendarski“, 2014, s. 135-141; CVETANOVA CVETKOVA, Zornica: Úloha e-testů ve výuce bulharštiny pro cizince. In: KREJČOVÁ, Elena - KREJČÍ, Pavel (eds.): Výuka jihoslovanských jazyků a literatur v dnešní Evropě. Brno: Občanské sdružení Porta Balkanica, 2014. s. 405-411; CVETANOVA CVETKOVA, Zornica: Avtentičnite materiali ot internet prostranstvoto kato alternativen podhod v komunikativno orientiranoto obučenie po bălgarski ezik za čuždenci. In: IVANOVA, Diana - ČOLAKOVA, Žoržeta (eds.): Paisievi četenija. Ezikoznanije. Naučni trudove, tom 51, kn.1, sb. B. Plovdiv: Universitetsko izdatelstvo „Paisij Chilendarski“, 2014, s. 349-356; NENIČKOVÁ, Veronika - SUDICKÝ, Petr: iPad in Academic Settings: A Pilot Project. In: BESEDA, Jan - MACHÁT, Zbyněk (eds.): DisCo 2014: Media literacy education from pupils to lifelong learning. Prague: Centre for Higher Education Studies, 201, s. 209-215 (studie byla spolufinancována specifickým výzkumem); NENIČKOVÁ, Veronika: Možnosti využití slovního mraku ve výuce cizího jazyka. In: KREJČOVÁ, Elena - KREJČ́́, Pavel (eds.): Výuka jihoslovanských jazyků a literatur v dnešní Evropě. Brno: Porta Balkanica, 2014. s. 253-265; NENIČKOVÁ, Veronika - SUDICKÝ, Petr: Tablet $v$ práci učitele. In: ROSECKÝ, Jan (ed.): Počítač ve škole 2014 - sborník př́ispěvků. Nové Město na Moravě: Gymnázium Vincence Makovského se sportovními tř́dami, 2014 (studie byla spolufinancována specifickým výzkumem).

8 KOLÁŘOVÁ, Kateřina: Časopisy Československo-jihoslovanské ligy: sonda do pramenů k dějinám meziválečných československo-jugoslávských stykư. Porta Balkanica VII, 2015, č. 1, s. 47-62; GUNIŠOVÁ, Eliška: Žánrové rozpätie tvorby Terézie Vansovej. Slavica litteraria 18, 2015, č. 2, s. 169-179; POSPÍŠIL, Ivo: Rusko a ruská literatura jako katalyzátor politického myšleni Tomáše G. Masaryka a několik souvislostí. Europa Masaryka - Jevropa Masarika - Evropa Masarykova, Colloquia Litteraria Sedlcensia, Studia Minora, volumen 7, 2, 2015, č. 1, s. 11-21; ŠPAČKOVÁ, Stanislava: The impact of political changes on the use of Latin script in Russian texts. Opera Slavica 25, 2015, č. 2, s. 47-58; TIMOFEEVA, Anastasiia - KUDRJAVCEVA, Ekaterina: Mifologizacija vlasti i globalizacija lichnosti: kinoobraz I. Stalina na zanjatii v vuze. Novaja rusistika/ Nová rusistika 8, 2015, č. 1, s. 62-68.

9 POSPÍŠIL, Ivo: Aksiologičeskij fenomen v „neistoričeskom romane “Jevgenija Vodolazkina „Lavr“. In: DOHNAL, Josef (ed.): Revitalizace hodnot: umění a literatura II. Brno: Ústav slavistiky Filozofické fakulty Masarykovy univerzity, 2015, s. 591-601; POSPÍŠIL, Ivo: Středni Evropa: posuny di̊razu. In: POSPÍŠIL, Ivo (ed.): Střední Evropa včera a dnes: proměny koncepcí. Kolektivní monografie. Brno: Jan Sojnek - nakladatelství Galium, 2015, s. 9-20.

10 BERGER, Olga: Semantičeskaja struktura terminov Predloženie i Prostoe predloženie na materiale russkih i češskih grammatik. In: DULEBOVÁ, Irina - POSOKHIN, Ivan (eds.): Mladá rusistika - nové tendencie a trendy III. Bratislava: STIMUL, 2015, s. 90-95; CVETANOVA CVETKOVA, Zornica: Multimedijnoto obučenie 
Také v roce 2015 byl z projektu podpořen (či přesněji řečeno částečně podpořen) vznik jedné disertace.

Jak již bylo zmíněno výše, v posledních letech se stalo pravidlem, že hlavním výstupem slavistického projektu je kolektivní publikace doktorando̊. Zatím takto vyšly tři publikace (Podoby a proměny města ve slovanských a vybraných neslovanských kulturách, literaturách a jazycích, Mladá slavistika: Současné trendy ve výzkumu slovanských literatur, jazyků a kultur a Slovanské literatury a jazyky $v$ objeti politiky (20. století), přičemž vedoucími autorského kolektivu byli doktorandi a mladí asistenti (resp. odborní asistenti) Ústavu slavistiky Michal Przybylski a Josef Šaur. ${ }^{11}$ Uvedené publikace byly recenzovány dvěma odbornými posuzovateli, a to jednak z toho důvodu, aby byla zajištěna jejich odborná úroveň, jednak také proto, aby se studenti seznámili s procesem hodnocení textů před jejich přijetím k otištění.

V roce 2016 řeší badatelský tým studentů a pracovníků Ústavu slavistiky projekt zaměřený na výzkum problematiky generačního konfliktu ve slovanských literaturách a kulturách. Také v případě tohoto projektu je plánován hlavní výstup v podobě kolektivní publikace.

Z dosavadních zkušeností s řešením projektů specifického vysokoškolského výzkumu plyne několik závěrů. V první řadě se projekty specifického výzkumu osvědčily jako iniciační, tj. stávají se platformou, díky níž vznikají první publikační výstupy části studentů doktorského studia. Ukazuje se totiž, že někteří studenti tíhnou k publikování „intuitivně“, jiné je však k této činnosti pobídnout, a v tomto ohledu plní specifický výzkum nezastupitelnou úlohu. $\mathrm{V}$ druhé řadě zmiňme, že díky těmto projektům každoročně roste počet publikačních výstupů realizovaných studenty doktorského studia. Část doktorandů se dokonce po prvních zkušenostech se specifickým výzkumem „osamostatňuje“, pravidelně vyjíždí na zahraniční konference a ti nejlepší dokonce publikuji již během řádného studia v zahraničních časopisech (a to dokonce i v těch zařazených do některé z prestižních databází). Jelikož jsou studenti za zapojení do řešení projektu odměňováni formou

po bălgarski ezik za čuždenci v Masarikovija unviersitet v Bărno. In: BOJKOVA, Fani - PETKOVA, Elena TOTKOV, Georgi (eds.): Ezik i literatura v e-obučenieto. Plovdiv: Rakursi, 2015. s. 140-156; CVETANOVA CVETKOVA, Zornica: Osobennosti funkcionirovanija glagolnogo vida v slavjanskich jazykah (syntaktiko-semantičesikij analiz glagolov). In: URKOM, Aleksander - VIRÓK, Attila (eds.): 3rd Conference for Young Slavists in Budapest. Budapest: István Lukács, 2015, s. 182-194; KRULIŠOVÁ, Kateřina Judith: Terorista revolucionár, narušování mýtu. In: DULEBOVÁ, Irina - POSOKHIN, Ivan (eds.): Mladá rusistika - nové tendencie a trendy III. Bratislava: STIMUL, 2015, s. 194-202; STRMISKA, Milan: Polská menšina v Žytomyrské oblasti. In: Ukrajinistika: minulost, přítomnost, budoucnost III: literatura a kultura. Eds. Halyna Myronova Oxana Čmelíková - Petr Kalina - Krystyna Kuznietsova - Ihor Shysterov. Brno: Jan Sojnek - Galium, 2015, s. 543-549; ŠPAČKOVÁ, Stanislava: K probleme peredači jediničnych antroponimov v mežjazykovoj kommunikacii. In: DULEBOVÁ, Irina - POSOKHIN, Ivan (eds.): Mladá rusistika - nové tendencie a trendy III. Bratislava: STIMUL, 2015, s. 125-134; ŠPAČKOVÁ, Stanislava: Cizi propria v ruských žurnalistických textech 19.-21. století. In: GAZDA, Jiří (ed.): Příspěvky k aktuálním otázkám jazykovědné rusistiky (4). Brno: Ústav slavistiky Filozofické fakulty Masarykovy univerzity, 2015, s. 145-150.

11 PRZYBYLSKI, Michal - ŠAUR, Josef a kol.: Podoby a proměny města ve slovanských a vybraných neslovanských kulturách, literaturách a jazycích. Brno: Masarykova univerzita, 2013; PRZYBYLSKI, Michal - ŠAUR, Josef a kol.: Mladá slavistika: Současné trendy ve výzkumu slovanských literatur, jazyků a kultur. Brno: Masarykova univerzita, 2014; POSPÍŠIL, Ivo - PRZYBYLSKI, Michal - ŠAUR, Josef a kol.: Slovanské literatury a jazyky v objeti politiky (20. století). Brno: Masarykova univerzita, 2015. 
stipendií, daří se tím (alespoň částečně) kompenzovat doktorandům tristní výši řádných stipendií v doktorském studiu, která má za následek skutečnost, že si doktorandi během studia musí přivydělávat a nakonec nevěnují studiu tolik úsilí, kolik by bylo třeba, či dokonce na jeho dokončení zcela rezignují. V neposlední řadě uved'me, že investice vložená do doktorandů se pak pozitivně vrací i samotné fakultě, potažmo univerzitě, nebot publikační činnost je jedním z kritérií pro tvorbu rozpočtů výzkumných institucí.

\section{Literatura}

BERGER, Olga: Semantičeskaja struktura terminov Predloženie i Prostoe predloženie na materiale russkih i češskih grammatik. In: DULEBOVÁ, Irina - POSOKHIN, Ivan (eds.): Mladá rusistika - nové tendencie a trendy III. Bratislava: STIMUL, 2015, s. 90-95.

CVETANOVA CVETKOVA, Zornica: Avtentičnite materiali ot internet prostranstvoto kato alternativen podhod v komunikativno orientiranoto obučenie po bălgarski ezik za čuždenci. In: IVANOVA, Diana - ČOLAKOVA, Žoržeta (eds.): Paisievi četenija. Ezikoznanije. Naučni trudove, tom 51, kn.1, sb. B. Plovdiv: Universitetsko izdatelstvo „Paisij Chilendarski“, 2014, s. 349-356.

CVETANOVA CVETKOVA, Zornica: Multimedijnoto obučenie po bălgarski ezik za čuždenci v Masarikovija unviersitet v Bărno. In: BOJKOVA, Fani - PETKOVA, Elena - TOTKOV, Georgi (eds.): Ezik i literatura v e-obučenieto. Plovdiv: Rakursi, 2015, s. 140-156.

CVETANOVA CVETKOVA, Zornica: Osobennosti funkcionirovanija glagolnogo vida v slavjanskich jazykah (syntaktiko-semantičesikij analiz glagolov). In: URKOM, Aleksander -VIRÓK, Attila (eds.): 3rd Conference for Young Slavists in Budapest. Budapest: István Lukács, 2015, s. 182-194.

CVETANOVA CVETKOVA, Zornica: Úloha e-testů ve výuce bulharštiny pro cizince. In: KREJČOVÁ, Elena - KREJČÍ, Pavel (eds.): Výuka jihoslovanských jazyků a literatur v dnešni Evropě. Brno: Občanské sdružení Porta Balkanica 6, 2014, s. 405-411.

GUNIŠOVÁ, Eliška: Žánrové rozpätie tvorby Terézie Vansovej. Slavica litteraria 18, 2015, č. 2, s. 169179.

KOLÁŘOVÁ, Kateřina: Časopisy Československo-jihoslovanské ligy: sonda do pramenů $k$ dějinám meziválečných československo-jugoslávských styků. Porta Balkanica 7, 2015, č. 1, s. 47-62.

KREJČÍ, Pavel: Hudebni motivy s numerickými komponenty v české, chorvatské, srbské a bulharské frazeologii. In: Frazeologické štúdie VI. Hudobné motívy vo frazeológii, 26. - 27. 9. 2014. Ed. Mária Dobríková. Bratislava: Univerzita Komenského v Bratislave, 2014, s. 168-179.

KREJČOVÁ, Elena: Frazeologizmi s komponent Tăpan/baraban v bălgarski ezik. In: Frazeologické štúdie VI. Hudobné motívy vo frazeológii, 26. - 27. 9. 2014. Ed. Mária Dobríková. Bratislava: Univerzita Komenského v Bratislave, 2014, s. 180-190.

KREJČOVÁ, Elena: Predizvikatelstvata pred novite uchebni pomagala po t.nar. „malki slavjanski ezici“. In: IVANOVA, Diana (ed.): Ezikova politika v evropejski i nacionalenkontekst. Plovdiv: Universitetsko izdatelstvo „Paisij Chilendarski“, 2014, s. 135-141.

KRULIŠOVÁ, Kateřina Judith: Terorista revolucionář, narušováni mýtu. In: DUBELOVÁ, Irina POSOKHIN, Ivan (eds.): Mladá rusistika - nové tendencie a trendy III. Bratislava: STIMUL, 2015, s. 194-202. 
NENIČKOVÁ, Veronika - SUDICKÝ, Petr: iPad in Academic Settings: A Pilot Project. In: BESEDA, Jan - MACHÁT, Zbyněk (eds.): DisCo 2014: Media literacy education from pupils to lifelong learning. Prague: Centre for Higher Education Studies, 2014, s. 209-215.

NENIČKOVÁ, Veronika - SUDICKÝ, Petr: Tablet v práci učitele. In: ROSECKÝ, Jan (ed.): Počítač ve škole 2014 - sborník příspěvků. Nové Město na Moravě: Gymnázium Vincence Makovského se sportovními tř́ídami, 2014.

NENIČKOVÁ, Veronika: Možnosti využití slovního mraku ve výuce ciziho jazyka. In: KREJČOVÁ, Elena - KREJČÍ, Pavel (eds.): Výuka jihoslovanských jazyků a literatur v dnešní Evropě. Brno: Porta Balkanica 6, 2014, s. 253-265.

POSPÍŠIL, Ivo - GAZDA, Jiří - HOLZER, Jan: Integrovaná žánrová typologie: (komparativni genologie): projekt, metodologie, terminologie, struktura oboru, studie. Brno: Masarykova univerzita, 1999.

POSPÍŠIL, Ivo - PRZYBYLSKI, Michal - ŠAUR, Josef a kol.: Slovanské literatury a jazyky v objetí politiky (20. století). Brno: Masarykova univerzita, 2015.

POSPÍŠIL, Ivo (ed.): Areál - sociálni vědy - filologie. Brno: Masarykova univerzita, 2002.

POSPÍŠIL, Ivo: Aksiologičeskij fenomen v „neistoričeskom romane“ Jevgenija Vodolazkina „Lavr“.

In: DOHNAL, Josef (ed.): Revitalizace hodnot: umění a literatura II. Brno: Ústav slavistiky Filozofické fakulty Masarykovy univerzity, 2015, s. 591-601.

POSPÍŠIL, Ivo: Areál a filologická studia. Brno: Masarykova univerzita, 2013.

POSPÍŠIL, Ivo: Cyrilometodějské výroči a problémy jeho současné recepce (Několik tezi a paradoxů misto úvodniho slova). Slavica litteraria 17, 2014, č. 1, s. 5-24.

POSPÍŠIL, Ivo: Rusko a ruská literatura jako katalyzátor politického myšleni Tomášse G. Masaryka a několik souvislostí. Europa Masaryka - Jevropa Masarika - Evropa Masarykova, Colloquia Litteraria Sedlcensia, Studia Minora, volumen 7, 2, 2015, č. 1, s. 11-21.

POSPÍŠIL, Ivo: Středni Evropa: posuny dưrazu. In: POSPÍŠIL, Ivo (ed.): Střední Evropa včera a dnes: proměny koncepcí. Kolektivní monografie. Brno: Jan Sojnek - nakladatelství Galium, 2015, s. 9-20. PRZYBYLSKI, Michal - ŠAUR, Josef a kol.: Mladá slavistika: Současné trendy ve výzkumu slovanských literatur, jazyki a kultur. Brno: Masarykova univerzita, 2014.

PRZYBYLSKI, Michal - ŠAUR, Josef a kol.: Podoby a proměny města ve slovanských a vybraných neslovanských kulturách, literaturách a jazycích. Brno: Masarykova univerzita, 2013.

STEHLÍK, Petr: Bosna, Zach i Načertanije: O nekim aspektima programa Ilije Garašanina iz 1844. godine. Slavistika 18, 2014, s. 353-360.

STRMISKA, Milan: Polská menšina v Žytomyrské oblasti. In: Ukrajinistika: minulost, př́ítomnost, budoucnost III: literatura a kultura. Eds. Halyna Myronova - Oxana Čmelíková - Petr Kalina - Krystyna Kuznietsova - Ihor Shysterov (eds.): Brno: Jan Sojnek - Galium, 2015, s. 543-549.

ŠPAČKOVÁ, Stanislava: Cizi propria v ruských žurnalistických textech 19.-21. století. In: GAZDA, Jiří (ed.): Př́íspěvky k aktuálním otázkám jazykovědné rusistiky (4). Brno: Ústav slavistiky Filozofické fakulty Masarykovy univerzity, 2015, s. 145-150.

ŠPAČKOVÁ, Stanislava: K probleme peredači jediničnych antroponimov v mežjazykovoj kommunikacii. In: DUBELOVÁ, Irina - POSOKHIN, Ivan (eds.): Mladá rusistika - nové tendencie a trendy III. Bratislava: STIMUL, 2015, s. 125-134.

ŠPAČKOVÁ, Stanislava: The impact of political changes on the use of Latin script in Russian texts. Opera Slavica 25, 2015, č. 2, s. 47-58. 
TIMOFEEVA, Anastasiia - KUDRJAVCEVA, Ekaterina: Mifologizacija vlasti i globalizacija lichnosti: kinoobraz I. Stalina na zanjatii v vuze. Novaja rusistika/Nová rusistika 8, 2015, č. 1, s. 62-68.

\section{Mgr. Josef Šaur, Ph.D.}

Ústav slavistiky

Filozofická fakulta, Masarykova univerzita

Arna Nováka 1, 60200 Brno, Česká republika

saur@phil.muni.cz 